\title{
ENDOSCOPIC MUCOSAL RESECTION IN COLORECTAL LESION: a safe and effective procedure even in lesions larger than $2 \mathrm{~cm}$ and in carcinomas
}

\author{
Carlos Eduardo Oliveira dos SANTOS ${ }^{1}$, Daniele MALAMAN ${ }^{1}$ and Julio Carlos PEREIRA-LIMA²
}

\begin{abstract}
Context - Endoscopic mucosal resection is a minimally invasive technique used in the treatment of colorectal neoplasms, including early carcinomas of different size and morphology. Objectives - To evaluate procedure safety, efficacy, outcomes, and recurrence rate in endoscopic mucosal resection of colorectal lesions. Methods - A total of 172 lesions in 156 patients were analyzed between May 2003 and May 2009. All lesions showed pit pattern suggestive of neoplasia (Kudo types III-V) at high-magnification chromocolonoscopy with indigo carmine. The lesions were evaluated for macroscopic classification, size, location, and histopathology. Lesions $20 \mathrm{~mm}$ or smaller were resected en bloc and lesions larger than $20 \mathrm{~mm}$ were removed using the piecemeal technique. Complications and recurrence were analyzed. Patients were followed up for 18 months. Results - There were 83 (48.2\%) superficial lesions, 57 (33.1\%) depressed lesions, 44 (25.6\%) laterally spreading tumors, and 45 (26.2\%) protruding lesions. Mean lesion size was $11.5 \mathrm{~mm} \pm 9.6 \mathrm{~mm}(2 \mathrm{~mm}-60 \mathrm{~mm})$. Patients' mean age was $61.6 \pm 12.5$ years (34-93 years). Regarding lesion site, $24(14.0 \%)$ lesions were located in the rectum, $68(39.5 \%)$ in the left colon, and $80(46.5 \%)$ in the right colon (transverse, ascending, and cecum). There were 167 (97.1\%) neoplasms: $142(82.5 \%)$ adenomatous lesions, $24(14.0 \%)$ intramucosal carcinomas, and $1(0.6 \%)$ invasive carcinoma. En bloc resection was performed in $158(91.9 \%)$ cases and piecemeal resection in $14(8.1 \%)$. Bleeding occurred in $5(2.9 \%)$ cases. Recurrence was observed in 4.1\% (5/122) of cases and was associated with lesions larger than $20 \mathrm{~mm}(P<0.01)$, piecemeal resection $(P<0.01)$, advanced neoplasm $(P=0.01)$, and carcinoma compared to adenoma $(P=0.04)$. Conclusions - Endoscopic mucosal resection of colorectal lesions is a safe and effective procedure, with low complication and local recurrence rates. Recurrence is associated with lesions larger than $20 \mathrm{~mm}$ and carcinomas.
\end{abstract}

HEADINGS - Colorectal neoplasms. Carcinoma. Endoscopy, gastrointestinal. Surgical procedures, minimally invasive. Treatment outcome.

\section{INTRODUCTION}

Endoscopic mucosal resection (EMR) was first reported by Tada et al. ${ }^{(46)}$. The procedure was initially used as a diagnostic method in gastric diseases, making it possible to obtain more tissue material than by conventional biopsy. It was later introduced as a treatment modality for early gastric cancer, becoming an attractive and less invasive therapeutic alternative to surgical resection. Indication for endoscopic resection has been accepted as a treatment modality for other early malignant tumors of the gastrointestinal tract, expanding the possibilities of endoscopic treatment to include superficial lesions (elevated and depressed types) ${ }^{(36)}$.

EMR is a minimally invasive, easy-to-learn, safe and effective technique used in the treatment of premalignant lesions and early carcinomas that have a low risk of lymph node metastasis. The most common technique is the 'inject and cut' EMR, originally described in 1973 by Deyhle et al. ${ }^{(7)}$. This technique involves the injection of saline solution into the submucosal layer under the lesion to be removed in order to lift the lesion and create a fluid cushion between the mucosa and the muscular wall, mitigating thermal effects on the organ wall, thus reducing the risk of perforation and bleeding and facilitating en bloc resection of lesions. Other variants of the technique include the use of 2-channel endoscopes, cap-fitted endoscopes, and band ligation. In addition to saline solution, other submucosal injection solutions include mannitol, sodium hyaluronate, dextrose, glycerol, fibrinogen, and hydroxypropyl methylcellulose ${ }^{(2,15,19,20,21)}$.

EMR has represented a major advance in therapy by allowing the resection of superficial lesions and also allowing the removal of large sessile lesions and laterally spreading tumors (LST). These larger lesions may be removed en bloc or in pieces (piecemeal resection). This

Departamento de Gastroenterologia da Santa Casa de Caridade, Bagé, RS; ${ }^{2}$ Fundação Riograndense Universitária de Gastroenterologia (FUGAST), Porto Alegre, RS, Brazil.

Correspondence: Dr. Carlos Eduardo Oliveira dos Santos - Rua Gomes Carneiro, 1343 - 96400-130 - Bagé, RS, Brazil. E-mail: clinica@endosantos.com.br 
method has made endoscopic treatment safer, minimizing the risk of complications.

The aim of this study was to evaluate the efficacy of EMR and recurrence rate of lesions in a consecutive series of patients with colorectal lesions with an indication for this procedure.

\section{METHODS}

\section{Study population}

A total of 172 endoscopic mucosal resections of colorectal lesions were performed on 156 patients between May 2003 and May 2009 in a private Endoscopy Unit in Southern Brazil in which approximately 800-1000 colonoscopies are carried out each year. Of the studied sample, 91 patients were women and mean age was $61.6 \pm 12.5$ years (34-93 years). Lesions were diagnosed by white light, and chromoscopy was then performed with $0.8 \%$ indigo carmine. All lesions underwent magnification examination (Fujinon EC-410 CM and 490 ZW5; Fujinon Corp., Saitama, Japan). All endoscopic resections were performed by a single endoscopist (CEOS). Based on Kudo's classification, lesions undergoing EMR showed pit pattern suggestive of neoplasia (Kudo types III-V) ${ }^{(27,28)}$.

Bowel preparation consisted of one-day clear liquid diet, with $10 \%$ mannitol solution, being considered appropriate in all study patients. Procedures were performed with the patient under conscious sedation (intravenous midazolam and meperidine).

The study was performed in accordance with the principles of the Declaration of Helsinki, and informed consent was obtained from all patients before endoscopy.

\section{Characteristics of lesions}

The morphology of lesions was determined according to the Paris classification, being divided into superficial lesions, protruding lesions, and LSTs ${ }^{(37)}$. Superficial lesions were defined as those not exceeding the height of the closed cups of a biopsy forceps and protruding lesions as those having a height above this threshold. LSTs were defined as lesions exceeding $10 \mathrm{~mm}$ in diameter, whether with a granular (sometimes nodular) or non-granular surface pattern. LSTs are characterized by lateral, circumferential and less vertical growth through the lumen of the colonic wall. Lesion size was estimated by comparison with a fully opened biopsy forceps (7 mm) (FB-24U-1; Olympus Medical Systems Corp., Tokyo, Japan). Regarding histopathological classification, lesions were divided into hyperplastic polyps, adenomas, and intramucosal carcinomas.

All lesions showed pit pattern suggestive of neoplasia (Kudo types III-V) and were analyzed by a single pathologist blinded to the endoscopic findings.

\section{Endoscopic resection}

EMR was indicated in cases of elevated and depressed superficial lesions, sessile lesions $10 \mathrm{~mm}$ or larger in diameter, and LSTs. The 'inject and cut' technique was performed, with submucosal injections of $4 \mathrm{~mL}-40 \mathrm{~mL}$ of hypertonic saline solution (4\% sodium chloride) using a sclerotherapy needle through the biopsy channel, lifting the lesion, retaining the lesion with a diathermal snare, and pressing it against the mucosa, with subsequent resection using coagulation current. Snare Master SD-210U-10 and SD-230U-20 polypectomy snares (Olympus Medical Systems Corp., Tokyo, Japan) were used for lesions $10 \mathrm{~mm}$ or smaller and larger than $10 \mathrm{~mm}$ in diameter, respectively.

Lesions $20 \mathrm{~mm}$ or smaller were resected en bloc and lesions larger than $20 \mathrm{~mm}$ were removed using the piecemeal technique, in a single session. After removal, specimens were mounted on Styrofoam plates and fixed in $10 \%$ formalin. The resection was considered complete if vertical and lateral margins were free from tumor tissue. The resection region was tattooed with India ink for lesions smaller than $1 \mathrm{~cm}$.

\section{Recurrence and follow-up}

Local recurrence was defined as the presence of neoplastic tissue on control colonoscopy in the area of previous resection. All study patients underwent follow-up colonoscopy at months 6, 12, and 18. Recurrent lesions were treated with a new EMR and were identified by the EMR scar.

\section{Statistical analysis}

Numerical variables were expressed as mean \pm standard deviation and categorical variables as percentage. Fisher's exact test was used for analysis of factors associated with the prevalence of complications and recurrence. Significance level was set at $5 \%$ for two-tailed tests.

\section{RESULTS}

All 172 colorectal lesions included in the study underwent EMR and high-magnification chromocolonoscopy with indigo carmine. The pit pattern observed was compatible with neoplasia (types IIIL, IIIs, IV, and Vi). This analysis had an influence on the treatment strategy for EMR of these lesions, since $97.1 \%$ (167/172) were neoplastic lesions.

According to the Paris classification, lesions were classified as follows: $83(48.2 \%)$ superficial lesions, $8(4.6 \%)$ type 0 -IIa, 18 (10.4\%) 0-IIa+dep, $24(14.0 \%)$ 0-IIa+IIc, 12 (7.0\%) 0-IIc+IIa, and $21(12.2 \%)$-IIc; $44(25.6 \%)$ LST; and $45(26.2 \%)$ protruding lesions, $40(23.3 \%) 0$-Is and $5(2.9 \%) 0$-Isp. The morphological appearance of lesions is described in Table 1.

TABLE 1. Morphological appearance of colorectal lesions

\begin{tabular}{lcc}
\hline Morphology & $\mathrm{n}$ & $\%$ \\
\hline 0-IIa & 8 & 4.6 \\
0-IIa+dep & 18 & 10.5 \\
0-IIa+IIc & 24 & 14.0 \\
0-IIc+IIa & 12 & 7.0 \\
0-IIc & 21 & 12.2 \\
0-Is & 40 & 23.3 \\
0-Isp & 5 & 2.9 \\
LST & 44 & 25.6 \\
\hline
\end{tabular}

LST $=$ laterally spreading tumor 
Regarding lesion size, $46(26.7 \%)$ were smaller than $5 \mathrm{~mm}$ in diameter, $51(29.7 \%)$ were $5 \mathrm{~mm}-10 \mathrm{~mm}, 61(35.5 \%)$ were 11 $\mathrm{mm}-20 \mathrm{~mm}$, and $14(8.1 \%)$ were larger than $20 \mathrm{~mm}$ (all LST). Mean lesion size was $11.5 \mathrm{~mm} \pm 9.6 \mathrm{~mm}(2 \mathrm{~mm}-60 \mathrm{~mm})$.

Regarding lesion site, $24(14.0 \%)$ lesions were located in the rectum, $41(23.8 \%)$ in the sigmoid colon, $27(15.7 \%)$ in the descending colon, $26(15.1 \%)$ in the transverse colon, $38(22.1 \%)$ in the ascending colon, and $16(9.3 \%)$ in the cecum.

Histological analysis revealed $167(97.1 \%)$ neoplastic and 5 $(2.9 \%)$ non-neoplastic lesions. There were $103(59.9 \%)$ tubular adenomas, $33(19.2 \%)$ tubulovillous adenomas, $2(1.1 \%)$ villous adenomas, $4(2.3 \%)$ serrated adenomas, $24(14.0 \%)$ intramucosal carcinomas, $1(0.6 \%)$ invasive carcinoma, and 5 $(2.9 \%)$ hyperplastic polyps (all smaller than $5 \mathrm{~mm}$ in diameter). Invasive carcinoma was associated with massive invasion of the submucosa, being referred for surgical resection.

En bloc resection was performed in 5 non-neoplastic lesions (all superficial microlesions with shallow depression), 135 adenomas, and 18 carcinomas. Piecemeal resection was performed in 7 adenomas and 7 carcinomas.

Resection was considered incomplete (lateral margins with histological evidence of malignancy) in $9.9 \%$ of lesions, with a significant difference between en bloc and piecemeal techniques ( 4.4 vs. $71.4 \%, P<0.001)$.

Complications included five $(2.9 \%)$ cases of immediate bleeding, which were managed endoscopically: epinephrine (1:10000) was injected in two cases, and argon plasma coagulation was used in three cases. Homeostasis was achieved in all cases. However, severe bleeding was observed after piecemeal resection of an LST of about $40 \mathrm{~mm}$ in length located in the cecum. Bleeding was controlled with argon plasma coagulation and the patient was kept under observation in the hospital. After 36 hours, radiographic examination revealed abdominal pain and free air in the abdominal cavity, and the patient was referred for surgical treatment. The case was diagnosed as intramucosal carcinoma.

Complications were more common in lesions larger than $20 \mathrm{~mm}$ that were removed using the piecemeal technique (14.3 vs $1.9 \%, P=0.05)$. No association was observed with histological type $(P=0.28)$ or between advanced and nonadvanced tumors $(P=0.35)$.

There were no cases of early or late bleeding, postpolypectomy syndrome, or death. A total of 122 lesions were successfully followed up 6,12, and 18 months after EMR. Recurrence was observed in $4.1 \%(5 / 122)$ of cases, with a significant association with lesions larger than $20 \mathrm{~mm}$ (all LST) removed using the piecemeal technique (30.8\% vs $0.9 \%, P<0.01$ ), advanced neoplasm (villous adenoma, highgrade dysplasia, lesions $1.0 \mathrm{~cm}$ or larger, and intramucosal carcinoma; $P=0.01)$, and carcinomas $(13.6 \%$ vs $2.0 \%$ adenomas, $P=0.04)$. In relation to total adenomas and carcinomas, recurrence rate was $1.4 \%$ and $12 \%$, respectively. There was no difference regarding sex $(P=0.65)$, age $(<60$ years and $\geq 60$ years), and distal segments as compared to the rest of the colon $(P=0.35)$.

Histopathological characteristics of colorectal lesions are described in Table 2. Lesions up to $20 \mathrm{~mm}$ in diameter
TABLE 2. Histological characteristics of colorectal lesions

\begin{tabular}{|c|c|c|c|}
\hline Characteristic & $\begin{array}{l}\text { Hyperplastic } \\
(\mathrm{n}=5)\end{array}$ & $\begin{array}{c}\text { Adenoma } \\
(\mathrm{n}=142)\end{array}$ & $\begin{array}{c}\text { Carcinoma } \\
(\mathrm{n}=25)\end{array}$ \\
\hline Age (years) & $63.4 \pm 12.6$ & $61.0 \pm 12.9$ & $66.2 \pm 9.0$ \\
\hline \multicolumn{4}{|l|}{ Sex } \\
\hline Female & $2(40)$ & $82(57.8)$ & $16(64)$ \\
\hline Male & $3(60)$ & $60(42.2)$ & $9(36)$ \\
\hline Size $(\mathrm{mm})$ & $2.2 \pm 0.5$ & $10.7 \pm 8.0$ & $17.7 \pm 14.8$ \\
\hline \multicolumn{4}{|l|}{ Size $(\mathrm{mm})$} \\
\hline$\leq 20$ & $5(100)$ & $135(95.1)$ & $18(72)$ \\
\hline$>20$ & $0(0)$ & $7(4.9)$ & $7(28)$ \\
\hline \multicolumn{4}{|c|}{ Macroscopic classification } \\
\hline Superficial & $5(100)$ & $169(48.6)$ & $9(36)$ \\
\hline Protruding & $0(0)$ & $39(27.5)$ & $6(24)$ \\
\hline LST & $0(0)$ & $34(23.9)$ & $10(40)$ \\
\hline \multicolumn{4}{|l|}{ Lesion site } \\
\hline $\mathrm{R}, \mathrm{S}$ & $4(80)$ & $53(37.3)$ & $8(32)$ \\
\hline $\mathrm{D}, \mathrm{T}, \mathrm{A}, \mathrm{C}$ & $1(20)$ & $89(62.7)$ & $17(68)$ \\
\hline \multicolumn{4}{|l|}{ Technique } \\
\hline En bloc & $5(100)$ & $135(95.1)$ & $18(72)$ \\
\hline Piecemeal & $0(0)$ & $7(4.9)$ & $7(28)$ \\
\hline \multicolumn{4}{|l|}{ Complication } \\
\hline No & $5(100)$ & 139 (97.9) & $23(92)$ \\
\hline Yes & $0(0)$ & $3(2.1)$ & $2(8)$ \\
\hline \multicolumn{4}{|l|}{ Recurrence } \\
\hline No & & $98(69.0)$ & $19(76)$ \\
\hline Yes & & $2(1.4)$ & $3(12)$ \\
\hline No follow-up & $5(100)$ & $42(29.6)$ & $3(12)$ \\
\hline
\end{tabular}

$\mathrm{A}=$ ascending colon; $\mathrm{C}=$ cecum; $\mathrm{D}=$ descending colon; $\mathrm{LST}=$ laterally spreading tumor; $\mathrm{R}$ $=$ rectum $; \mathrm{S}=$ sigmoid colon $; \mathrm{T}=$ transverse colon

were resected en bloc, and recurrence was observed in one patient with LST of $20 \mathrm{~mm}$ in length $(0.9 \%, 1 / 109)$. All cases of recurrence were observed on the first control colonoscopy, 6 months after resection. Recurrent lesions were treated with a new EMR, with complete removal of lesions. No lesion was found at 12- or 18-months follow-up.

\section{DISCUSSION}

EMR is a less invasive alternative to surgical removal of adenomas, including large-size tumors ${ }^{(1,32,34,44)}$, intramucosal carcinoma, and minimally invasive submucosal carcinoma ${ }^{(13,29,38)}$. Furthermore, Tanaka et al. ${ }^{(47)}$ reported that well- or moderately differentiated carcinomas within $1,500 \mu \mathrm{m}$ invasion are curative by EMR, provided that no vascular involvement is observed.

Several studies have shown the efficacy of high-magnification chromocolonoscopy, through pit pattern analysis, in differentiating neoplastic from non-neoplastic lesions, with an accuracy of $80.1 \%$ to $99.1 \%{ }^{(10,12,16,23,26,40,43,50,51)}$. Recent studies have reported an agreement of $96.8 \%$ for lesions up to $2.0 \mathrm{~cm}$ and $94.9 \%$ for lesions up to $1.0 \mathrm{~cm}$ in diameter ${ }^{(9,41)}$. In the present study, out of 172 lesions undergoing EMR, 167 were neoplasms, showing an accuracy of $97.1 \%$. 
In our study, complete resection was achieved in $90.1 \%$ $(155 / 172)$ of cases, with a statistically significant difference between en bloc and piecemeal techniques $(P<0.001)$, a finding similar to that of Hurlstone et al. ${ }^{(17)}$ of 12 vs $97 \%$, respectively $(P<0.001)$.

Bleeding is considered the most common complication, occurring in $0.4 \%$ to $16 \%$ of cases $^{(8,15,32,48)}$. Ferrara et al. ${ }^{(10)}$ concluded that bleeding was significantly related to malignancy, as observed in one of our cases. Perforation has been reported as occurring in $0 \%$ to $4 \%$ of cases $^{(3,15,18,22)}$. Caputi et al. ${ }^{(5)}$ reported in their series $2.3 \%$ of perforation after EMR (all polypoid carcinomas). Swan et al. ${ }^{(45)}$ described a target sign as a marker of muscularis propria resection and, therefore, potential perforation during EMR of colorectal lesions, with an incidence of 3.8\% for en bloc resection and 1.6\% for piecemeal resection $(P=0.16)$. Prompt recognition of this sign allows immediate closure with endoscopic clips. In the present study, complications (all post-EMR immediate bleeding) occurred in $2.9 \%$ of cases. Although bleeding was managed endoscopically, one case progressed to perforation $(0.6 \%)$ after hemostasis with APC. It should be emphasized that hemostasis in the cecum with mechanical methods such as clips are theoretically safer than by thermal means such as APC. However, in the given case the bleeding was diffuse, hindering the use of clips. None of these patients used antiinflammatory drugs or had any coagulopathy. Intercurrent events occurred more significantly in lesions larger than $20 \mathrm{~mm}$ in diameter that underwent piecemeal resection $(P=0.05)$.

Regarding recurrence, data in the literature range from $1.2 \%$ to $55 \%(14,19,31,44,54)$. Most series have reported a higher recurrence rate associated with piecemeal resection as compared to en bloc resection ${ }^{(11,31,33)}$. Although our findings are consistent with most previous studies, Lim et al. ${ }^{(30)}$ found no difference between the two techniques.

Follow-up is essential due to the risk of recurrence ${ }^{(39)}$. Current guidelines recommend performing control colonoscopies between 3 and 6 months for large polyps undergoing piecemeal resection ${ }^{(53)}$. However, there is no consensus on the approach to detection of residual polyp in a follow-up examination. We conducted a strict follow-up, and only patients who underwent follow-up colonoscopy at months 6,12 , and 18 were included in this study. We were able to follow-up about $70 \%$ of patients.

In the present study, recurrence showed a statistically significant difference for lesions larger than $20 \mathrm{~mm}$ in diameter removed by piecemeal $(P<0.01)$, for advanced neoplasms $(P=0.01)$, and for carcinomas $(P=0.04)$. Seo et al ${ }^{(42)}$ showed a higher recurrence rate after piecemeal resection for malignant polyps $(33.3 \%)$ than for benign polyps $(3.1 \%)(P<0.05)$. Conio et al. ${ }^{(6)}$ noted similar recurrence rates. However, conflicting data exist concerning the use of argon plasma coagulation as an adjunct to piecemeal resection to reduce recurrence of neoplasms ${ }^{(4,14,33,54)}$. Studies have demonstrated late recurrence after piecemeal resection of large sessile lesions, which may be a result of the presence of residual dysplastic tissue that is not visible on the first follow-up examinations, developing over time ${ }^{(24,52)}$. These results highlight the importance of strict monitoring.

Evidently, the greater recurrence of lesions larger than $2 \mathrm{~cm}$ appears to be related to the piecemeal technique rather than to lesion size. To reduce recurrence rates, endoscopic submucosal dissection (ESD), developed in recent years, has been proposed for resection of gastrointestinal tumors larger than 1-2 cm. ESD has been recently used in the treatment of superficial colorectal cancer, and its main indications are: en bloc removal of lesions larger than $2 \mathrm{~cm}$, thus reducing the risk of recurrence; lesions showing pit pattern Vi at high-magnification; large protruding lesions suspected to be carcinomas; lesions with fibrosis due to previous biopsies; and post-EMR residual carcinoma ${ }^{25,35,49)}$. However, this method presents technical difficulty, has a long procedure time, without a steep learning curve, and shows a perforation rate significantly higher than that of EMR.

\section{CONCLUSIONS}

Endoscopic mucosal resection is a therapeutic method that allows the curative treatment of colorectal neoplasms. This is a safe and effective procedure, with low rates of complication and recurrence, which can be removed by endoscopic retreatment. Patients with malignant lesions larger than $2 \mathrm{~cm}$ have higher recurrence and immediate complication rates. 
Santos CEO, Malaman D, Pereira-Lima JC. Mucosectomia em lesões do cólon e reto: procedimento seguro e eficaz mesmo em pacientes com lesões maiores que $2 \mathrm{~cm}$ e em carcinomas. Arq Gastroenterol. 2011;48(4);242-7.

RESUMO - Contexto - A mucosectomia endoscópica é uma técnica minimamente invasiva para o tratamento de neoplasias de cólon e reto, inclusive carcinomas precoces, de diferentes tamanhos e aspectos morfológicos. Objetivo - Avaliar a segurança, a eficácia, os resultados e a recurrência das lesões após mucosectomia. Métodos - Entre maio de 2003 e maio de 2009 um total de 172 lesões em 156 pacientes foi incluído no estudo. Todas as lesões tinham padrão de criptas sugestivo de neoplasias (III-V), segundo a classificação de Kudo, com o diagnóstico feito por colonoscópios com magnificação de imagens e índigo-carmin. As lesões foram avaliadas quanto à macroscopia, tamanho, localização e histopatologia. Lesões com até $20 \mathrm{~mm}$ foram removidas em bloco e as maiores que $20 \mathrm{~mm}$ pela técnica de piecemeal. Complicações e recurrência foram analisadas. O seguimento foi de 18 meses. Resultados - Este estudo identificou 83 (48,2\%) lesões superficiais, sendo 57 (33,1\%) deprimidas, além de 44 ( $25,6 \%)$ lesões de espraiamento lateral e $45(26,2 \%)$ protrusas. O tamanho médio foi de 11,5 $\pm 9,6 \mathrm{~mm}(2-60 \mathrm{~mm})$ e a idade média de $61,6 \pm 12,5$ anos (34-93 anos). No reto estavam $24(14 \%)$ lesões, 68 (39,5\%) no cólon esquerdo e 80 (46,5\%) no cólon direito (transverso, ascendente e ceco). Foram 167 (97,1\%) neoplasias, sendo $142(82,5 \%)$ lesões adenomatosas, $24(14,0 \%)$ carcinomas intramucosos e $1(0,6 \%)$ carcinoma invasivo. Foram tratadas em bloco $158(91,9 \%)$ lesões e $14(8,1 \%)$, por piecemeal. Houve cinco casos $(2,9 \%)$ de sangramento. A recurrência foi de 4,1\% (5/122) e associada a lesões maiores que 20 mm $(P<0,01)$, à técnica piecemeal $(P<0,01)$, à neoplasia avançada $(P=0,01)$ e ao carcinoma quando comparado ao adenoma $(P=0,04)$. Conclusões - A mucosectomia endoscópica de lesões colorretais é procedimento seguro, eficaz, com baixo índice de complicações e recidiva local. A recidiva de lesão é associada a lesões maiores que $20 \mathrm{~mm}$ e aos carcinomas.

DESCRITORES - Neoplasias colorretais. Carcinoma. Endoscopia gastrointestinal. Procedimentos cirúrgicos minimamente invasivo.

\section{REFERENCES}

1. Ahmad NA, Kochman ML, Long WB, Furth EE, Ginsberg GG. Efficacy, safety, and clinical outcomes of endoscopic mucosal resection: a study of 101 cases Gastrointest Endosc. 2002;55:390-6.

2. Arantes V, Albuquerque W, Benfica E, Duarte DL, Lima D, Vilela S, Lima G, Sakai P, Filho FM, Artifon E, Halwan B, Kumar A. Submucosal injection of $0.4 \%$ hydroxypropyl methylcellulose facilitates endoscopic mucosal resection of gastrointestinal tumors. J Clin Gastroenterol. 2010;44:615-9.

3. Bergmann U, Beger HG. Endoscopic mucosal resection for advanced nonpolypoid colorectal adenoma and early stage carcinoma. Surg Endosc. 2003;17:475-9.

4. Brooker JC, Saunders BP, Shah SG, Thapar CJ, Suzuki N, Williams CB. Treatment with argon plasma coagulation reduces recurrence after piecemeal resection of large sessile colonic polyps: a randomized trial and recommendations. Gastrointest Endosc. 2002;55:371-5.

5. Caputi Iambrenghi O, Ugenti I, Martines G, Marino F, Francesco Altomare D, Memeo V. Endoscopic management of large colorectal polyps. Int J Colorectal Dis. 2009; 24:749-53.

6. Conio M, Repici A, Demarquay JF, Blanchi S, Dumas R, Filiberti R. EMR of large sessile colorectal polyps. Gastrointest Endosc. 2004;60:234-41.

7. Deyhle P, Largiader F, Jenny S, Fumagalli I. A method for endoscopic electroresection of sessile colonic polyps. Endoscopy. 1973;5:38-40.

8. Doniec JM, Löhnert MS, Schniewind B, Bokelmann F, Grimm H. Endoscopic removal of large colorectal polyps: prevention of unnecessary surgery? Dis Colon Rectum 2003;46:340-8.

9. dos Santos CE, Pereira-Lima JC, Lopes CV, Malaman D, Salomão AD, Garcia AC, Teixeira CR. Computerized virtual chromoendoscopy versus indigo carmine chromoendoscopy combined with magnification for diagnosis of small colorectal lesions: a randomized and prospective study. Eur J Gastroenterol Hepatol. 2010;22:1364-71.

10. Emura F, Saito Y, Taniguchi M, Fujii T, Tagawa K, Yamakado M. Further validation of magnifying chromocolonoscopy for differentiating colorectal neoplastic polyps in a health screening center. J Gastroenterol Hepatol. 2007;22:1722-7.

11. Ferrara F, Luigiano C, Ghersi S, Fabbri C, Bassi M, Landi P, Polifemo AM, Billi P, Cennamo V, Consolo P, Alibrandi A, D'Imperio N. Efficacy, safety and outcomes of 'inject and cut' endoscopic mucosal resection for large sessile and flat colorectal polyps. Digestion. 2010;82:213-20.

12. Fu KI, Sano Y, Kato S, Fujii T, Nagashima F, Yoshino T, Okuno T, Yoshida S, Fujimori T. Chromoendoscopy using indigo carmine dye spraying with magnifying observation is the most reliable method for differential diagnosis between nonneoplastic and neoplastic colorectal lesions: a prospective study. Endoscopy. 2004;36:1089-93.

13. Fujiya M, Moriichi K, Saitoh Y, Watari J, Kohgo Y. Endoscopic piecemeal resection is a practical option to cure colorectal tumors. Dig Endosc. 2009;21:s28-30.

14. Fukami N, Lee JH. Endoscopic treatment of large sessile and flat colorectal lesions. Curr Opin Gastroenterol. 2006;22:54-9.
15. Hirasaki S, Kozu T, Yamamoto H, Sano Y, Yahagi N, Oyama T, Shimoda T, Sugano K, Tajiri H, Takekoshi T, Saito D. Usefulness and safety of $0.4 \%$ sodium hyaluronate solution as a submucosal fluid "cushion" for endoscopic resection of colorectal mucosal neoplasms: a prospective multi-center open-label trial. BMC Gastroenterol. 2009;9:1.

16. Hurlstone DP, Cross SS, Adam I, Shorthouse AJ, Brown S, Sanders DS, Lobo AJ Efficacy of high magnification chromoscopic colonoscopy for the diagnosis of neoplasia in flat and depressed lesions of the colorectum: a prospective analysis. Gut. 2004;53:284-90.

17. Hurlstone DP, Cross SS, Brown S, Sanders DS, Lobo AJ. A prospective evaluation of high magnification-chromoscopic colonoscopy in predicting completeness of EMR. Gastrointest Endosc. 2004;59:642-50.

18. Hurlstone DP, Cross SS, Drew K, Adam I, Shorthouse AJ, Brown S, Sanders DS, Lobo AJ. An evaluation of colorectal endoscopic mucosal resection using high-magnification chromoscopic colonoscopy: a prospective study of 1000 colonoscopies. Endoscopy. 2004;36:491-8.

19. Hurlstone DP, Fu KI, Brown SR, Thomson M, Atkinson R, Tiffin N, Cross SS. EMR using dextrose solution versus sodium hyaluronate for colorectal Paris type I and 0-II lesions: a randomized endoscopist-blinded study. Endoscopy. 2008;40:110-4.

20. Hyun JJ, Chun HR, Chun HJ, Jeen YT, Baeck CW, Yu SK, Kim YS, Lee HS, Um SH, Lee SW, Choi JH, Kim CD, Ryu HS, Hyun JH. Comparison of the characteristics of submucosal injection solutions used in endoscopic mucosal resection. Scand J Gastroenterol. 2006;41:488-92.

21. Iishi H, Tatsuta M, Iseki K, Narahara H, Uedo N, Sakai N, Ishikawa H, Otani T, Ishiguro S. Endoscopic piecemeal resection with submucosal saline injection of large sessile colorectal polyps. Gastrointest Endosc. 2000;51:697-700.

22. Jameel JK, Pillinger SH, Moncur P, Tsai HH, Duthie GS. Endoscopic mucosal resection (EMR) in the management of large colo-rectal polyps. Colorectal Dis. 2006;8:497-500

23. Kato S, Fu KI, Sano Y, Fujii T, Saito Y, Matsuda T, Koba I, Yoshida S, Fujimori T. Magnifying colonoscopy as a non-biopsy technique for differential diagnosis of non-neoplastic and neoplastic lesions. World J Gastroenterol. 2006;12:1416-20.

24. Khashab M, Eid E, Rusche M, Rex DK. Incidence and predictors of "late" recurrences after endoscopic piecemeal resection of large sessile adenomas. Gastrointest Endosc. 2009;70:344-9.

25. Kobayashi N, Saito Y, Uraoka T, Matsuda T, Suzuki H, Fujii T. Treatment strategy for laterally spreading tumors in Japan: before and after the introduction of endoscopic submucosal dissection. J Gastroenterol Hepatol. 2009;24:1387-92.

26. Konishi K, Kaneko K, Kurahashi T, Yamamoto T, Kushima M, Kanda A, Tajiri $\mathrm{H}$, Mitamura K. A comparison of magnifying and nonmagnifying colonoscopy for diagnosis of colorectal polyps: a prospective study. Gastrointest Endosc. 2003;57:48-53.

27. Kudo S, Hirota S, Nakajima T, Hosobe S, Kusaka H, Kobayashi T, Himori M, Yahyuu AA. Colorectal tumours and pit pattern. J Clin Pathol. 1994;47:880-5.

28. Kudo S, Tamura S, Nakajima T, Yamano H, Kusaka H, Watanabe H. Diagnosis of colorectal tumours lesions by magnifying endoscopy. Gastrointest Endosc. 1996;44:8-14. 
29. Kudo S, Tamegai Y, Yamano H, Imai Y, Kogure E, Kashida H. Endoscopic mucosal resection of the colon: the Japanese technique. Gastrointest Endosc Clin N Am. 2001;11:519-35.

30. Lim TR, Mahesh V, Singh S, Tan BH, Elsadig M, Radhakrishnan N, Conlong P Babbs C, George R. Endoscopic mucosal resection of colorectal polyps in typical UK hospitals. World J Gastroenterol. 2010;16:5324-8.

31. Luigiano C, Consolo P, Scaffidi MG, Strangio G, Giacobbe G, Alibrandi A, Pallio S, Tortora A, Melita G, Familiari L. Endoscopic mucosal resection for large and giant sessile and flat colorectal polyps: a single-center experience with long-term follow-up. Endoscopy. 2009;41:829-35.

32. Mahadeva S, Rembacken BJ. Standard "inject and cut" endoscopic mucosal resection technique is practical and effective in the management of superficial colorectal neoplasms. Surg Endosc. 2009;23:417-22.

33. Mannath J, Subramanian V, Singh R, Telakis E, Ragunath K. Polyp recurrence after endoscopic mucosal resection of sessile and flat colonic adenomas. Dig Dis Sci. 2011.

34. Marc G, Lopes CV. Endoscopic resection of superficial gastrointestinal tumors. World J Gastroenterol. 2008;14:4600-6.

35. Oka S, Tanaka S, Kanao H, Ishikawa H, Watanabe T, Igarashi M, Saito Y, Ikematsu H, Kobayashi K, Inoue Y, Yahagi N, Tsuda S, Simizu S, Iishi H, Yamano H, Kudo SE, Tsuruta O, Tamura S, Saito Y, Cho E, Fujii T, Sano Y, Nakamura H, Sugihara K, Muto T. Current status in the occurrence of postoperative bleeding, perforation and residual/local recurrence during colonoscopic treatment in Japan. Dig Endosc. 2010;22:376-80.

36. Parada AA, Scarparo JIB, Santos CE. Terapêutica das lesões superficiais do cólon e reto. In: Sociedade Brasileira de Endoscopia Digestiva. Endoscopia digestiva diagnóstica e terapêutica. Rio de Janeiro: Revinter; 2005. p.613-24.

37. The Paris endoscopic classification of superficial neoplastic lesions: esophagus, stomach and colon: November 30 to December 1, 2002. Gastrointest Endosc. 2003;58(6 Suppl):s44-5.

38. Repici A, Pellicano R, Strangio G, Danese S, Fagoonee S, Malesci A. Endoscopic mucosal resection for early colorectal neoplasia: pathologic basis, procedures, and outcomes. Dis Colon Rectum. 2009;52:1502-15.

39. Rostirolla RA, Pereira-Lima JC, Teixeira CR, Schuch AW, Perazzoli C, Saul C. [Development of colorectal advanced neoplasia/adenomas in the long-term followup of patients submitted to colonoscopy with polipectomy]. Arq Gastroenterol. 2009;46:167-72.

40. Santos CE. Magnificação de imagem: cólon e reto. In: Sociedade Brasileira de Endoscopia Digestiva. Endoscopia gastrointestinal terapêutica. São Paulo: Techmed Editora; 2006. p.180-8.

41. Santos CE, Pereira-Lima JC, Lopes CV, Malaman D, Parada AA, Salomão AD. [Comparative study between MBI (FICE) and magnification chromoendoscopy with indigo carmine in the differential diagnosis of neoplastic and non-neoplastic lesions of the colorectum]. Arq Gastroenterol. 2009;46:111-5.

42. Seo GJ, Sohn DK, Han KS, Hong CW, Kim BC, Park JW, Choi HS, Chang HJ,
Oh JH. Recurrence after endoscopic piecemeal mucosal resection for large sessile colorectal polyps. World J Gastroenterol. 2010;16:2806-11.

43. Su MY, Ho YP, Chen PC, Chiu CT, Wu CS, Hsu CM, Tung SY. Magnifying endoscopy with indigo carmine contrast for differential diagnosis of neoplastic and nonneoplastic colonic polyps. Dig Dis Sci. 2004;49:1123-7.

44. Su MY, Hsu CM, Ho YP, Lien JM, Lin CJ, Chiu CT, Chen PC, Tung SY, Wu CS. Endoscopic mucosal resection for colonic non-polypoid neoplasms. Am J Gastroenterol. 2005; 100:2174-9

45. Swan MP, Bourke MJ, Moss A, Williams SJ, Hopper A, Metz A. The target sign an endoscopic marker for the resection of the muscularis propria and potentia perforation during colonic endoscopic mucosal resection. Gastrointest Endosc. 2011;73:79-85.

46. Tada M, Shimada M, Yanai H. Development of a new method of endoscopic biopsy: "strip biopsy". Stomach Intestine. 1984;19:1109-116.

47. Tanaka S, Haruma K, Oh-E H, Nagata S, Hirota Y, Furudoi A, Amioka T, Kitadai Y, Yoshihara M, Shimamoto F. Conditions of curability after endoscopic resection for colorectal carcinoma with submucosally massive invasion. Oncol Rep. 2000;7:783-8

48. Tanaka S, Haruma K, Oka S, Takahashi R, Kunihiro M, Kitadai Y, Yoshihara M, Shimamoto F, Chayama K. Clinicopathologic features and endoscopic treatment of superficially spreading colorectal neoplasms larger than $20 \mathrm{~mm}$. Gastrointest Endosc. 2001;54:62-6.

49. Tanaka S, Oka S, Chayama K. Colorectal endoscopic submucosal dissection present status and future perspective, including its differentiation from endoscopic mucosal resection. J Gastroenterol. 2008;43:641-51.

50. Togashi K, Konishi F, Ishizuka T, Sato T, Senba S, Kanazawa K. Efficacy of magnifying endoscopy in the differential diagnosis of neoplastic and non-neoplastic polyps of the large bowel. Dis Colon Rectum. 1999;42:1602-8.

51. Tung SY, Wu CS, Su MY. Magnifying colonoscopy in differentiating neoplastic from nonneoplastic colorectal lesions. Am J Gastroenterol. 2001;96:2628-32.

52. Walsh RM, Ackroyd FW, Shellito PC. Endoscopic resection of large sessile colorectal polyps. Gastrointest Endosc. 1992;38;303-9.

53. Winawer SJ, Zauber AG, Fletcher RH, Stillman JS, O’Brian MJ, Levin B, Smith RA, Lieberman DA, Burt RW, Levin TR, Bond JH, Brooks D, Byers T, Hyman N, Kirk L, Thorson A, Simmang C, Johnson D, Rex DK; US Multi-Society Task Force on Colorectal Cancer; American Cancer Society. Guidelines for colonoscopy surveillance after polypectomy: a consensus update by the US Multi-Society Task Force on Colorectal Cancer and the American Cancer Society. Gastroenterology. 2006; 130:1872-85

54. Zlatanic J, Waye JD, Kim PS, Baiocco PJ, Gleim GW. Large sessile colonic adenomas: use of argon plasma coagulator to supplement piecemeal snare polypectomy. Gastrointest Endosc. 1999;49:731-5. 